\title{
RTDF2007-46013
}

\section{IMPROVED TANK CAR SAFETY RESEARCH}

\author{
David Tyrell \\ David Jeong \\ Karina Jacobsen \\ Volpe National Transportation Systems Center \\ Cambridge, Massachusetts, USA
}

\author{
Eloy Martinez \\ Federal Railroad Administration \\ Washington, DC, USA
}

\section{ABSTRACT}

Three recent accidents involving the release of hazardous material have focused attention on the structural integrity of railroad tank cars: (1) Minot, ND, on January 18, 2002; (2) Macdona, TX, on June 28, 2004; and (3) Graniteville, SC, on January 6, 2005. Each of these accidents resulted in fatalities. Research is being conducted to develop strategies for improving railroad tank cars so they can maintain tank integrity in severe accidents. A collaborative effort called the Next Generation Rail Tank Car (NGRTC) Project intends to use these research results to help develop improved tank car designs. Dow Chemical Company, Union Pacific Railroad, and Union Tank Car Company are the industry sponsors of the NGRTC Project. The Federal Railroad Administration (FRA) and Transport Canada participate in the NGRTC project through Memoranda of Cooperation. FRA and the Pipeline and Hazardous Materials Safety Administration intend to use these research results to support rulemaking.

The approach taken in performing this research is to define the collision conditions of concern, to evaluate the behavior of current design equipment in these scenarios, and to develop alternative strategies for increasing the maximum impact speed for which tank integrity is maintained.

The accident scenarios have been developed from a review of accidents and are intended to bound the range of main-line accidents that can lead to a release of hazardous material from a tank car. The accident scenarios and collision modes have been used to define car-to-car impact scenarios. These car-to-car impact scenarios define the conditions under which the commodity must be contained. The impact scenarios are being used to evaluate the integrity of current design and improved design tank cars.

Full-scale impact tests are also being conducted, to help validate modeling of the baseline equipment. The models have been refined based on the test results. The models are now being applied to develop the improved equipment designs.
This paper describes the overall research framework and provides an overview of the research done to date, as well as the planned efforts.

\section{INTRODUCTION}

The safe transport of hazardous materials (hazmat) is a key concern of the Federal Railroad Administration (FRA). Moreover, the objective of FRA-sponsored research is to maintain tank integrity under various loading conditions. Data from the FRA's Railroad Accident and Incident Reporting System (RAIRS) show that the number of accidents per year with at least 1 car releasing hazardous materials has decreased significantly over the past 25 years (Figure 1). The decrease is attributed to improvements in tank car designs and to Federal regulations that instituted requirements for head shields, thermal protection, and double self couplers - each of which reduces the likelihood of rupturing a tank car during an accident.

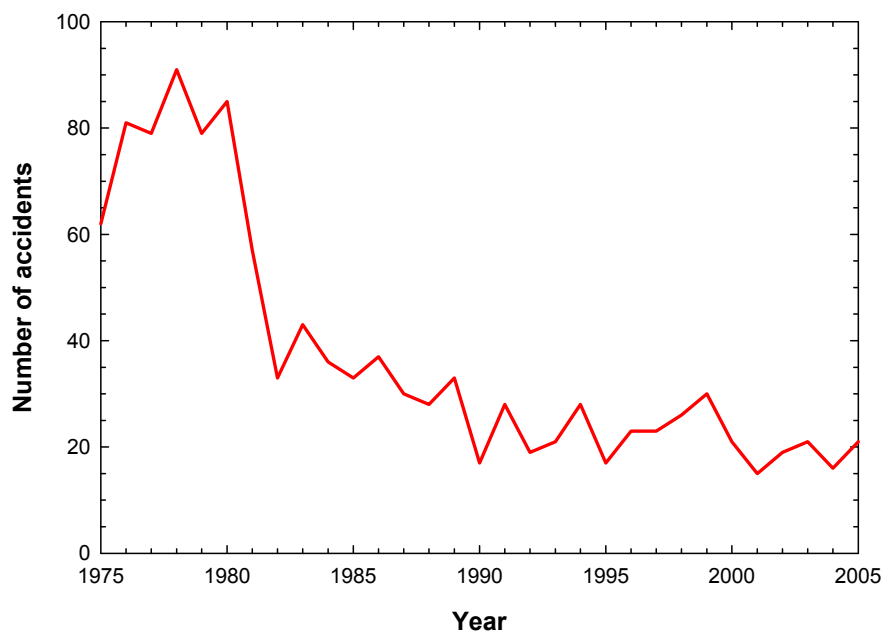

Figure 1. Number of Accidents with at Least One Car Releasing Hazardous Materials 
Although accident statistics show that the rail industry's safety performance has generally improved over the last few decades, three recent accidents involving the release of hazmat have focused attention on the structural integrity of railroad tank cars under extreme or accident loading conditions: (1) Minot, ND, on January 18, 2002 [1]; (2) Macdona, TX, on June 28, 2004 [2]; and (3) Graniteville, SC, on January 6, 2005 [3]. Consequently, the focus of FRA tank car safety research shifted from maintaining tank integrity under normal tank car operating conditions (e.g., metal fatigue and crack propagation) to maintaining tank integrity under accident loading conditions. In order to evaluate tank performance in accident loading conditions, collision dynamics and structural response must be considered in addition to material behavior. Figure 2 shows a timeline of events related to railroad tank car safety since the Minot accident in 2002 to the present.

An industry research and development effort began in 2006, called the Next Generation Rail Tank Car (NGRTC) Project [4]. Dow Chemical Company, Union Pacific Railroad (UP), and Union Tank Car Company (UTLX) are the sponsors of this collaboration. In 2006, FRA and the Pipeline and Hazardous Materials Safety Administration (PHMSA) initiated a Notice of Proposed Rulemaking (NPRM) for transporting hazmat by railroad tank cars [5].

Government and industry-sponsored research is being conducted to develop strategies for improving railroad tank cars so they can maintain tank integrity for more severe accident conditions than current equipment. FRA and PHMSA intend to use these research results to support rulemaking, and the NGRTC Project intends to use these research results to help develop improved tank car designs. FRA and Transport Canada also participate in the NGRTC Project through Memoranda of Cooperation (MOC). The Volpe National Transportation Systems Center (Volpe Center) is providing technical support to FRA in the rulemaking process and the NGRTC Project. As described in the press release issued by FRA on January 16, 2007 [6]:

[FRA Administrator Joseph H.] Boardman said the FRA has signed a Memorandum of Cooperation (MOC) with Dow Chemical Company, Union Pacific Railroad and the Union Tank Car Company to participate in their Next Generation Rail Tank Car Project. The agreement provides for extensive information sharing and cooperation between ongoing FRA and industry research programs to improve the safety of rail shipments of hazardous commodities such as toxic inhalation hazards and high-risk gases and liquids.

This paper describes the overall approach for this research, as well as the necessary tasks and the organizations which will perform the tasks. Companion papers describe ongoing modeling [7, 8] and full-scale testing [9], as well as tank car design strategies for improving protection of the commodity [10].

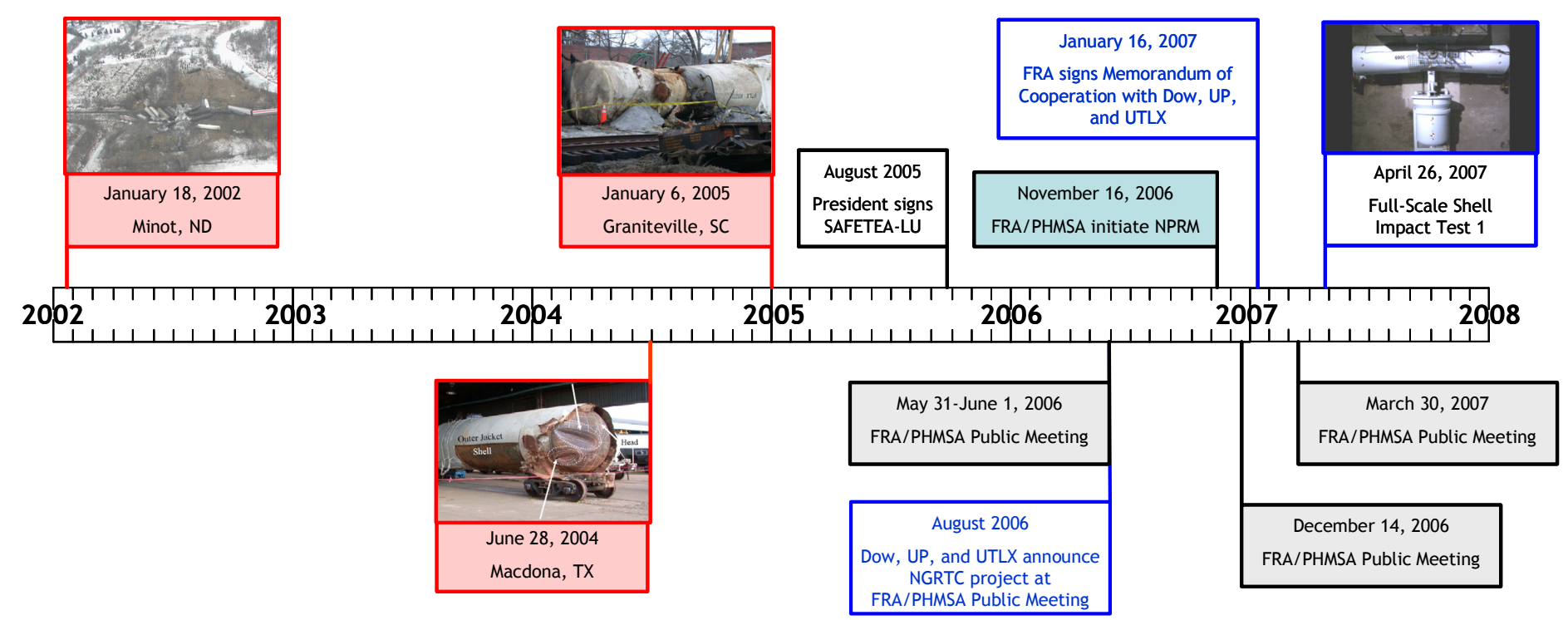

FRA/Volpe Tank Car Safety Research:

Damage Tolerance and Fatigue Crack Growth

Extreme/Accident Loading Conditions

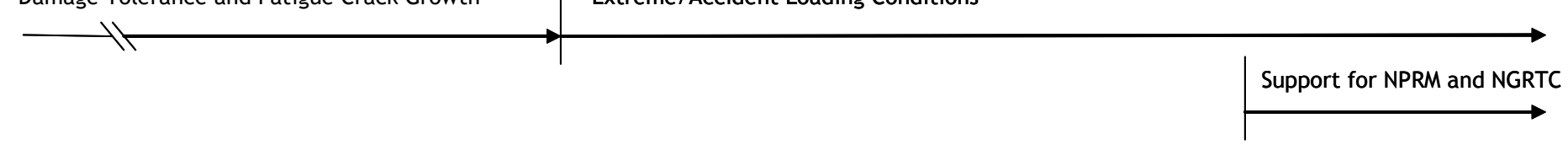

Figure 2. Timeline of Events Related to Railroad Tank Car Safety 


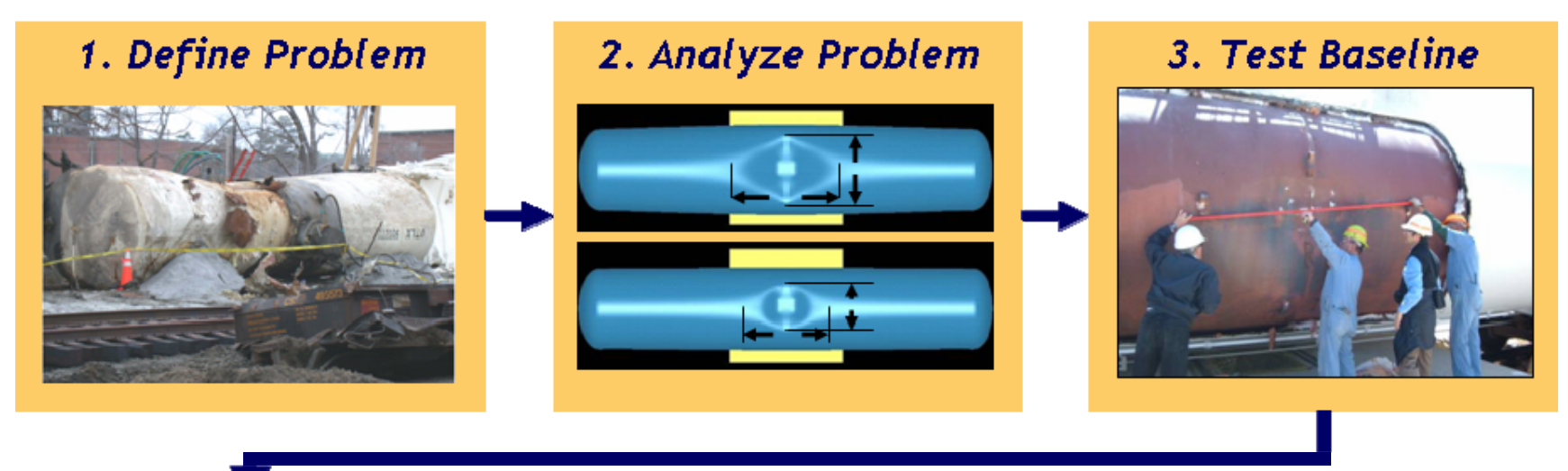

\section{Refine Simulation}

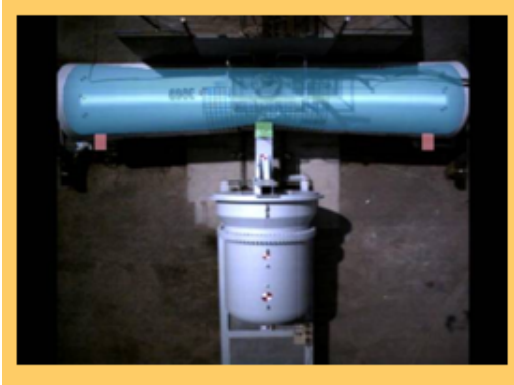

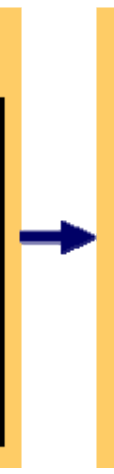

5. Develop Improved Design

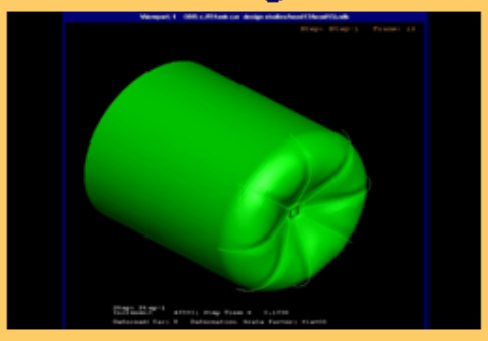

6. Evaluate Improved Design

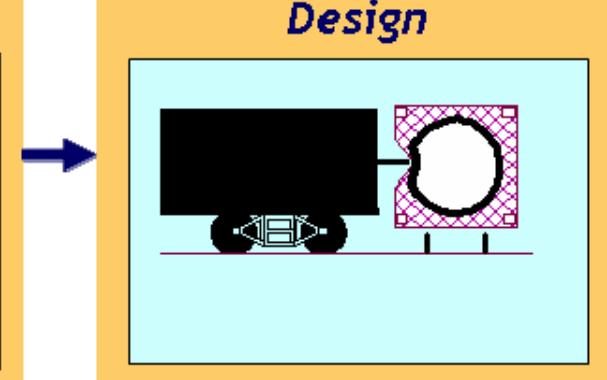

Figure 3. Research Steps to Develop Improved Tank Car Design

\section{APPROACH}

The approach taken in performing this research is to define the collision conditions of concern, to evaluate the behavior of current design equipment in these scenarios, and to develop alternative strategies for increasing the impact speed associated with maintaining tank integrity in these scenarios. The evaluations of the current equipment and alternative strategies are being accomplished iteratively, with analytic models of increasing complexity. Full-scale impact tests are also being planned, in part to help validate modeling, as well as to directly compare the effectiveness of current and alternative equipment designs. Figure 3 shows a schematic representation of the research steps.

\section{Definition of Problem: Generalized Accident and Impact Scenarios}

The accident scenarios involving hazardous material release from tank cars have been developed from a review of accidents. These are intended to bound the range of accidents that can lead to a release of hazardous material from a tank car. These accident scenarios include derailments and collisions, which are listed in Table 1, along with example accidents and the collision mode that results in lading loss. The accident scenarios and collision modes have been used to define car-tocar impact scenarios, which define impact conditions under which the commodity must be contained. The impact scenarios are used to evaluate the integrity of current and improved design tank cars. The performance of improved equipment is compared with the performance of baseline equipment in the impact scenarios.

Table 1. Accident Scenarios of Concern

\begin{tabular}{|l|l|l|}
\hline & Accident Scenario & Collision Modes \\
\hline 1 & $\begin{array}{l}\text { Derailment } \\
\text { Minot, ND, January 18, 2002 }\end{array}$ & $\begin{array}{l}\text { Head and Shell } \\
\text { Impacts }\end{array}$ \\
\hline 2 & $\begin{array}{l}\text { Train-to-Train Collision } \\
\text { Graniteville, SC, January 6, 2005 }\end{array}$ & $\begin{array}{l}\text { Override, Head } \\
\text { and Shell Impacts }\end{array}$ \\
\hline
\end{tabular}

Figures 4 and 5 show possible outcomes of extreme loading conditions for head and shell collision modes. Figure 4 shows an example of a head puncture, which is a photograph of the chlorine tank car damaged in the train collision that occurred in Macdona, TX, on June 28, 2004. The denting and puncture of the tank car resulted from a collision with a flat car. Figure 5 shows an example of a shell puncture, which is a computer-generated image of the damage to the chlorine tank car in the train collision that occurred in Graniteville, SC, on January 6,2005 . The computer-generated image is produced from three-dimensional laser measurements taken from the tank car. Moreover, puncture of the tank shell is attributed to impact from a broken coupler. 


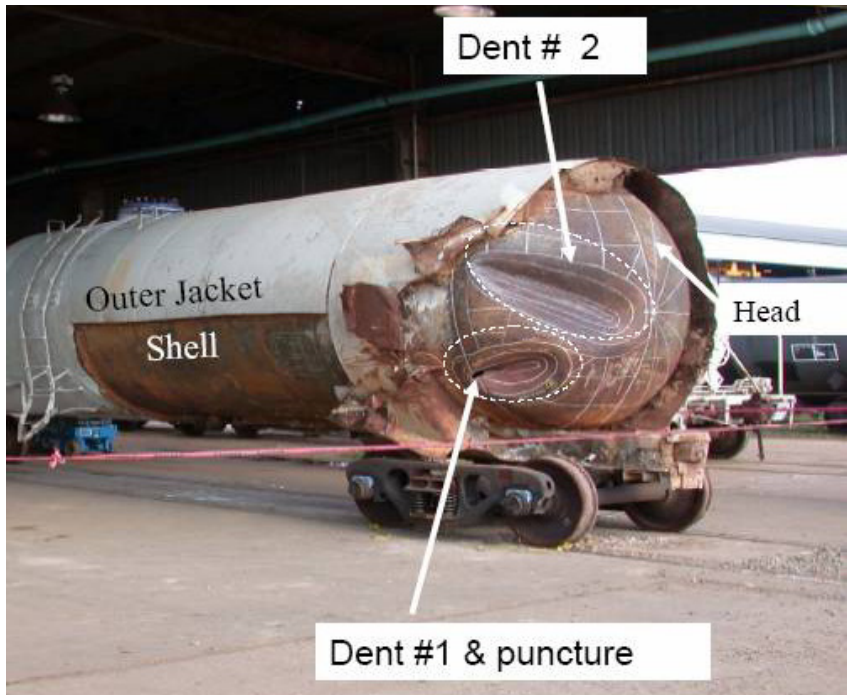

Figure 4. Head Puncture from Macdona Accident

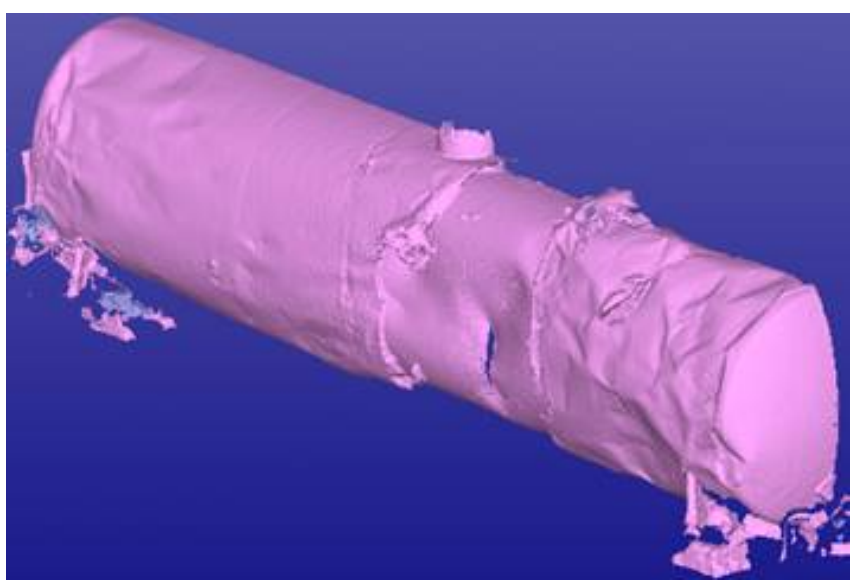

Figure 5. Shell Puncture from Graniteville Accident

One of the research activities being performed by the Volpe Center on accident loading conditions is analysis of derailment dynamics to examine the gross motions of rail cars during a train derailment [7, 11]. Moreover, the models for derailment dynamics produce car-to-car impacts that resemble those in accidents. Figure 6(a) shows car motions (in plan view) at two instants of time from an idealized derailment simulation. The two particular instants of time show car-to-car impacts for imminent head and shell impacts, respectively, which are encircled in the figure. The model results indicate that such head and shell impacts within the train consist occur at about one-half of the initial train speed at the point of derailment. Figure 6(b) shows the generalized head and shell impact scenarios schematically. In each scenario, the tank cars are essentially full. In the head impact, the coupler of one tank car impacts the head of a second tank car. In the shell impact, the coupler of one tank car impacts the side (shell) of a second tank car.

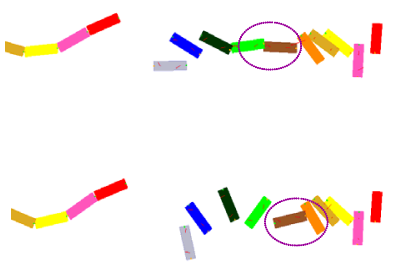

(a) Accident simulation

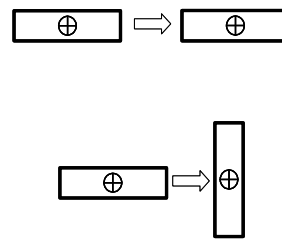

(b) Generalized impact scenario
Figure 6. Generalized Car-to-Car Impact Scenarios

For a prescribed closing speed, the generalized car-to-car impact conditions, illustrated in Figure 6, are used to develop energy absorption requirements for the tank car. The Volpe Center is using these generalized impact scenarios as design requirements to drive the development of the improved tank car conceptual design [10].

\section{Baseline Analysis}

In evaluating the performance of current equipment, a DOT 105 car is considered as the baseline tank car. Table 2 lists the key attributes associated with a typical chlorine tank car.

Table 2. Summary of Attributes for a Typical Chlorine Tank Car

\begin{tabular}{|l|l|}
\hline Commodity & Chlorine \\
\hline Gross Weight & $263,000 \mathrm{lb}$ \\
\hline Tank Inside Diameter & 100.625 inches \\
\hline Head Thickness (Material) & 0.828 inch (TC-128B) \\
\hline Shell Thickness (Material) & 0.777 inch (TC-128B) \\
\hline Jacket (Material) & 0.119 inch (A1011) \\
\hline Internal Pressure & $100 \mathrm{psi}$ \\
\hline Outage & $10.6 \%$ \\
\hline
\end{tabular}

Nonlinear (i.e., elastic-plastic) finite element analysis of the baseline car is performed using commercial solvers, namely, ABAQUS and LS-DYNA. Such analyses have been used to evaluate the performance of the baseline car in a range of impact conditions. The key output of the finite element models is the force-indentation characteristic (see Figure 7) of the tank as it is struck by an impacting object, such as a coupler or wheel from an adjacent rail car. Moreover, the basis for evaluating the performance of various tank car designs is the energy to failure or the area under the force-indentation characteristic, which, in turn, is related to the impact velocity to cause failure through kinetic energy. That is, the velocity at which failure of the tank may be expected is proportional to the square root of the energy or area under the force-indentation curve. The specific point at which failure may occur on the force-indentation curve depends on several factors, such as size and shape of the impacting object and material properties. 


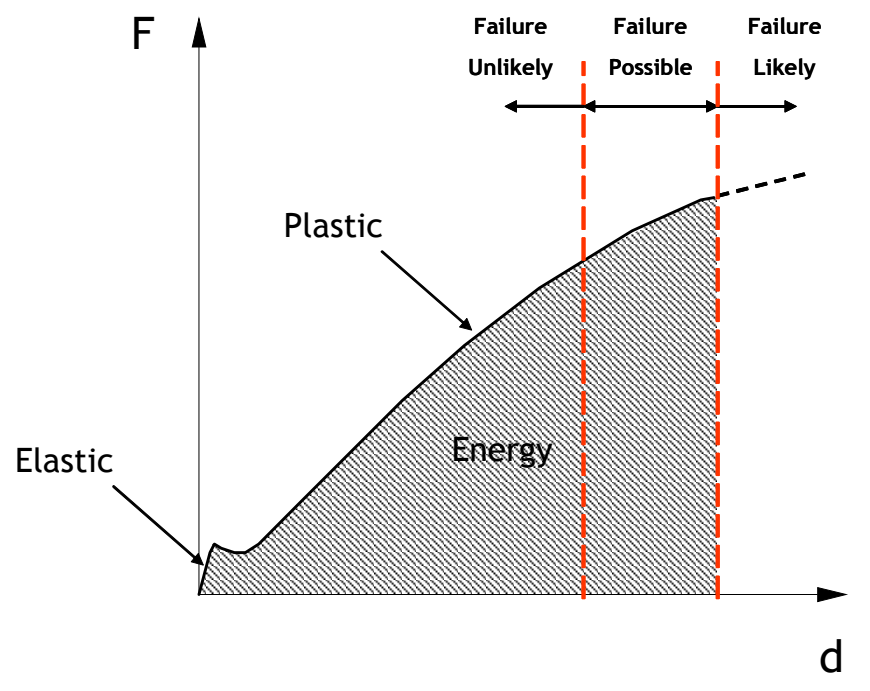

Figure 7. Generic Force-Indentation Characteristic

Credibility and confidence in the finite element modeling are achieved through verification and validation studies. Results from static, nonlinear finite element analyses are compared to closed-form solutions for rigid-plastic deformations of cylindrical shells to verify the model development. Results from dynamic, nonlinear finite element analyses are compared to test data to validate the models. In this context, verification means that the mathematics of the models are being calculated correctly, while validation means that the physics are being modeled properly.

Figure 8 shows the deformation of an ellipsoidal end cap or tank car head, calculated from closed-form and finite element analyses. The closed-form solution assumes rigidplastic material behavior and calculates axisymmetric deformation due to a concentrated load applied at the center. In the finite element analysis, elastic-plastic material behavior is assumed as the load is applied over a rectangular area at the center. Despite the differences in material behavior and applied load, the calculated deformations are nearly the same.

\section{Closed-Form Solution}

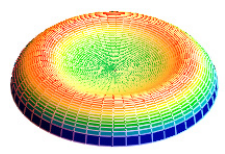

- Rigid-plastic material behavior

- Concentrated load

\section{Finite Element Analysis}

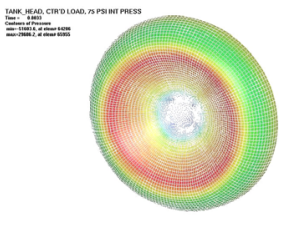

- Elastic-plastic material behavior - Rectangular punch load
Figure 8. Deformation of Ellipsoidal Cap

Figure 9 shows the force-indentation curves corresponding to the closed-form and finite element analyses. Despite the differences in assumptions, the curves are in close agreement. Moreover, the results shown in the two previous figures provide verification of the finite element analyses for head impact. Similar calculations have been performed to verify the analyses for shell impacts [9]. The analyses will be validated with data from full-scale and component tests.

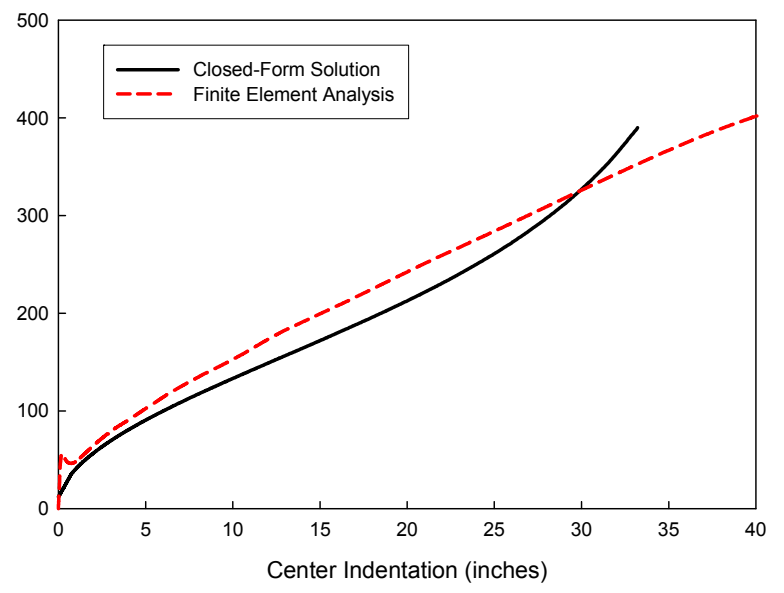

Figure 9. Comparison Between Closed-Form Solution and Finite Element Analysis for Head Indentation

The Volpe Center is applying the verified and validated analyses to examine the performance of baseline and improved tank car designs in a range of impact conditions. The baseline analysis results establish the reference for assessing potential improvements. The potentially improved designs are evaluated for the same conditions (e.g., the generalized head and shell impact scenarios) with the same analysis techniques, and the resulting differences in performance are compared.

\section{Full-Scale Testing and Analysis Refinement}

A series of full-scale shell impact tests was performed at the Transportation Technology Center in Pueblo, CO, in 2007. The purpose of the shell impact tests is to establish the crashworthiness performance of existing tank cars.

Figure 10 shows a flow chart of the activities required for the successful implementation of the full-scale tests. FRA coordinated with the Volpe Center to design these tests using simplified models. Dow Chemical collaborated with Applied Research Associates, Inc. (ARA) in developing more detailed simulation models that supported the Transportation Technology Center, Inc. (TTCI) in implementation of the tests.

The Volpe analyses include closed-form and finite element analysis, which accounts for fluid-structure interaction, material failure and basic tank car geometry (no body bolster, stub sill, etc.) [9]. The simplified model was used to develop the test requirements and test design. These results provide the basis for more detailed tank car models. 


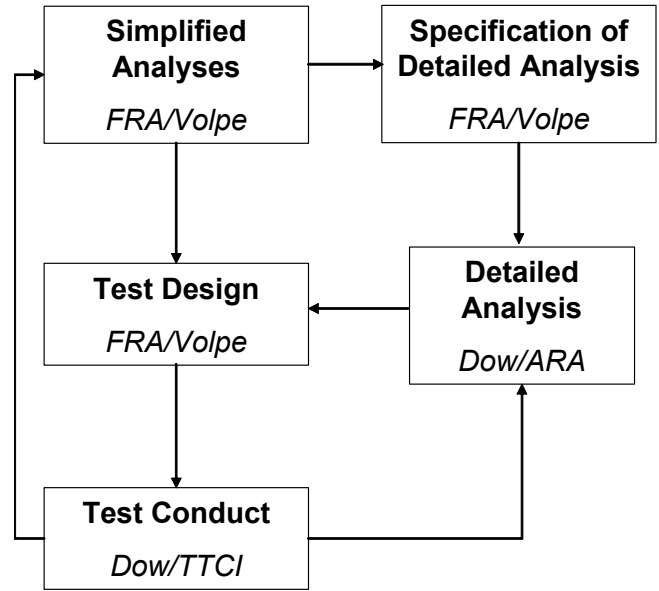

Figure 10. Flow Chart of Activities Supporting Full-Scale Tests

The detailed analysis model developed by ARA includes a detailed description of the car geometry, including the body bolster, stub sills, and fittings. These simulations are used to verify the test requirements, particularly the test speed.

The test requirements include descriptions of the track, initial positions of equipment, impact speed, and measurements needed for comparison with the analyses. These measurements enable verification of the analyses, as well as measure the information needed to improve the analyses if the predications and test results disagree.

A Test Implementation Plan (TIP) is needed for appropriate and safe implementation of the test. The TIP describes the test equipment, setup, instrumentation, data acquisition system, and conduct of the test, including safety procedures.

Figure 11 illustrates the shell impact test scenario. The tank car was positioned with the centerline perpendicular to the tracks and supported by a fixed barrier on one side. The tank car contained clay slurry, which approximated a typical load of chlorine. The side of the tank car was impacted with a ram car traveling at an initial velocity. The ram car was a ballasted flatcar with an indenter protruding from the lead end.
Both the ram car and tank car were instrumented with accelerometers, string potentiometers, strain gages, and pressure transducers to measure the impact forces experienced by the tank car, gross motions in three-dimensions of the ram car and tank car, the pressure gradient within the tank, and dent size and material strains of the tank car shell. High-speed digital video cameras were used to document the motions of the ram car and tank car, as well as the progression of the tank car deformation during the impact. Two tests of this arrangement have been conducted, one with a punch size too large to cause puncture and one with a punch size sufficiently small to cause puncture. In this way, the bounds of the 'Failure Possible' region shown in Figure 7 have been measured.

On April 26, 2007, tank car shell impact test 1 was conducted [9]. A ram car traveling at $14 \mathrm{mph}$ impacted the side of a stationary tank car with the characteristics listed in Table 2. The indenter of the ram car deformed the shell to a maximum dent depth of 26 inches, without puncturing the tank car shell. The face of the indenter was 23 inches wide and 17 inches high, approximately the cross-section size of a freight car draft sill.

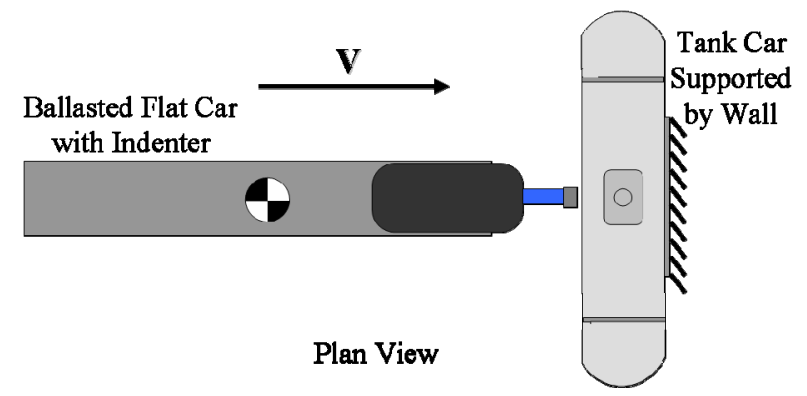

Figure 11. Schematic of Full-Scale Shell Impact Test

Figure 12 shows still photographs from the high-speed cameras of Test 1 . The three stills show the time at which (1) the indenter of the ram car makes contact with the tank car, (2) the maximum penetration of the indenter into the tank, and (3) the final dent size after the indenter has rebounded off the tank car.
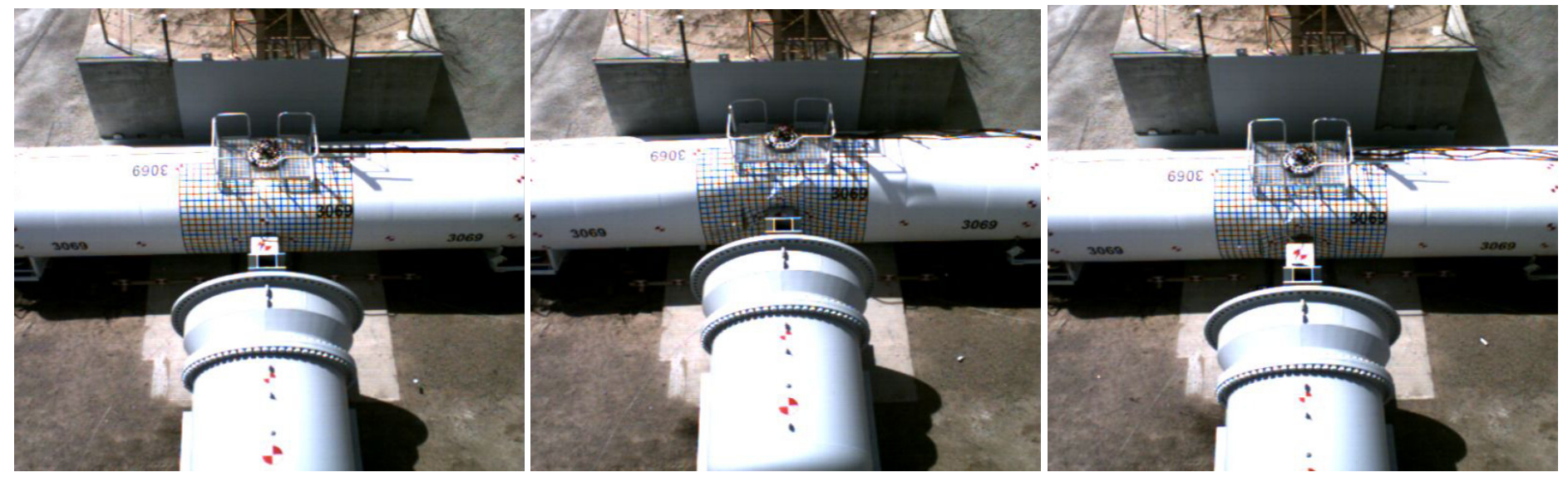

Figure 12. Stills from Test 1 

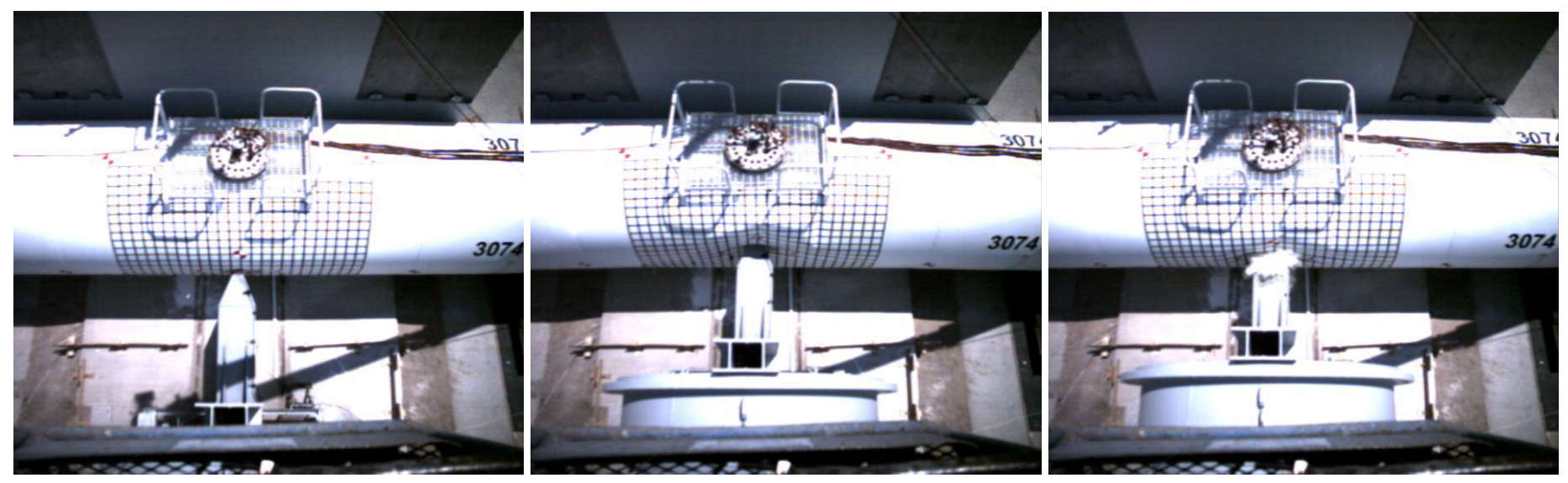

Figure 13. Stills from Test 2

The simplified finite element analysis model closely predicted force-time histories in both of the shell impact tests [9]. The pre-test model for test 1 estimated the peak force within 10 percent of the measured test data, and the dent size to within 15 percent. The discrepancy results from the exclusion of the jacket in the modeled tank car and the assumption of conservative (minimum) material properties for the shell. As a result, the model estimates a somewhat larger dent at a slightly lower load than the test results, as shown by the data presented in Table 3.

Table 3. Comparison Between Test 1 and Analysis

\begin{tabular}{|l|c|c|}
\hline & $\begin{array}{c}\text { Maximum } \\
\text { Force (kips) }\end{array}$ & $\begin{array}{c}\text { Maximum } \\
\text { Dent (inches) }\end{array}$ \\
\hline Test 1 Data & 1290 & 26 \\
\hline Finite Element Analysis & 1170 & 30 \\
\hline
\end{tabular}

On July 11, 2007, tank car shell impact test 2 was conducted [9]. A ram car traveling at $15 \mathrm{mph}$ impacted the side of a stationary tank. The indenter of the ram car punctured the tank car shell. The face of the indenter was 6 inches wide and 6 inches high, approximately the cross-section size coupler shank.

Figure 13 shows still photographs from the high-speed cameras of Test 2. The three stills show the time at which (1) the indenter of the ram car makes contact with the tank car, (2) the maximum penetration of the indenter into the tank, and (3) just after the indenter has punctured the tank car.

The pre-test estimates closely matched the principal results for both tests [9]; however, the measurements have been used to refine the models and provide a high level of confidence in the evaluation of improved designs. These refined analysis techniques are being used with a high level of confidence to evaluate alternative improved designs.

\section{Development and Evaluation of Improved Design}

The objective of FRA tank car research is to develop strategies for improving railroad tank cars so that tank integrity is maintained for more severe accident conditions than current equipment. As discussed above, the full-scale testing of conventional tank car equipment establishes a baseline representation of crashworthiness performance of tank car equipment currently in operation. Figure 14 shows the development of concepts for an improved tank car design. Each step incrementally generates more detail on improved concepts.

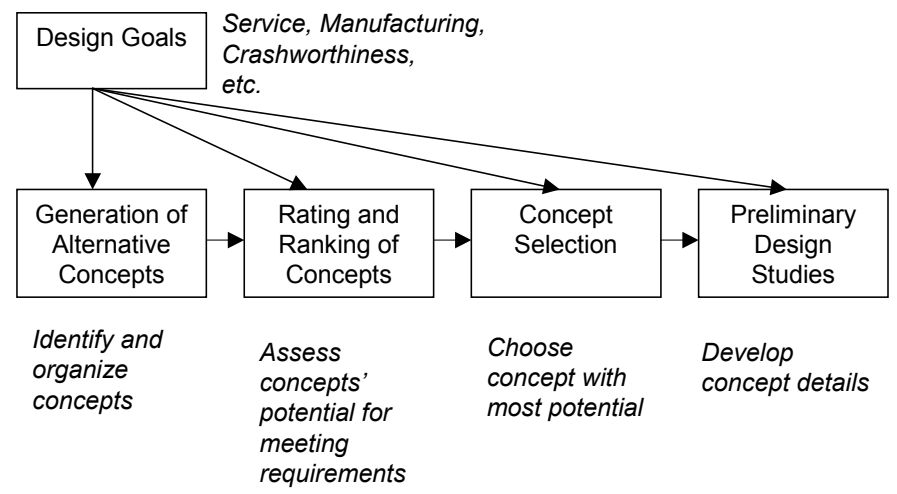

Figure 14. Schematic of Improved Design Development

Table 4 lists the functions and associated features of the conceptual design. These functions are needed to meet the impact requirements of a head impact and shell impact. The conceptual design must perform four functions to meet the impact requirements: blunt the impact loads, absorb collision energy, strengthen the tank, and assure that any impact loads are first blunted and that a significant amount of energy is absorbed before the tank is loaded.

Table 4. Improved Design Functions and Features

\begin{tabular}{|l|l|}
\hline \multicolumn{1}{|c|}{ Functions } & \multicolumn{1}{c|}{ Features } \\
\hline Blunted impact loads & $\begin{array}{l}\text { Sacrificial structure that shields } \\
\text { tank and absorbs energy }\end{array}$ \\
\cline { 1 - 2 } Collision energy absorbed & Reinforcement of head and shell \\
\hline Stronger tank & Carbody supports service loads \\
\hline Control load path to tank
\end{tabular}


Head shields on current cars principally act to blunt the impact load. In essence, the shield makes the size of the impacting object appear larger to the tank, spreading the load over a greater area. By doing so, the energy required to rupture the tank is increased. The addition of an energy absorption component between the shield and the tank can further increase the energy required to rupture the tank. The energy absorption layer decreases the speed of the impact experienced by the tank.

Strengthening the tank allows an energy absorption component to crush at a higher load. If the tank remains the main service load-bearing structure, then the potential for weldments to lead to fatigue failures is of concern. In such a case, bonding the stiffeners to head and shell is a potential option. If the service load-bearing structure is separate from the commodity tank, and the tank does not experience cyclic service loads, then the potential for fatigue failure is much lower. In such a case, directly welding to the head and shell may be a viable option.

Accident history suggests that rupture can initiate anywhere on the tank. Ruptures are more likely at certain locations on the tank-below the beltline and at the ends of the cars. Some cars, however, appear to have been ruptured by impacts near the draft sill/body bolster and on the top. These accident results suggest that the entire car should be shielded and that collision energy should be absorbed before the tank is impacted. In order to accomplish this function, a separate carbody structure supports the service loads.

Figure 15 shows a schematic of the features integrated into a conceptual design. Potentially, these features could be applied incrementally to existing designs, working from the inside out. The tank could be strengthened with bonded stiffeners alone. As described in a companion paper [10], such stiffeners have the potential to double the energy required to rupture the tank. A sacrificial structure for blunting the load and absorbing energy could be further added. The stiffeners and sacrificial structure could increase the energy required to rupture the tank by a factor of four for most impacts. Such a car would be at least somewhat more vulnerable near the draft sill/body bolster attachments, even if these attachments act as structural fuses and fail in a prescribed manner for prescribed loads. Impact loads that bypass the sacrificial structure could be introduced to the tank through the Achilles' heel of the draft sill/body bolster. The external carbody would eliminate this vulnerability and result in the integrated conceptual design. For example, the continuous center sill design relieves the tank from bearing the in-train buff and draft forces and continues to be used in DOT 105A500W tank cars built for carbon dioxide service.

While information is being shared, the design development activities supported by Dow Chemical are separate and distinct from the design development activities being conducted by the Volpe Center in support of FRA. In the process chosen by FRA and the Volpe Center, an overall strategy is evolved into a single concept with required functions and features. These features are then refined into detailed forms with preliminary design studies. This approach has been used to develop crush zones for passenger equipment [12, 13, 14], the state-of-the-art cab car end frame design [15], and improved locomotive crashworthiness features [16], as well as improved workstation tables [17], optimized commuter seats [18], and a conceptual design for inflatable structures for train operator protection [19].

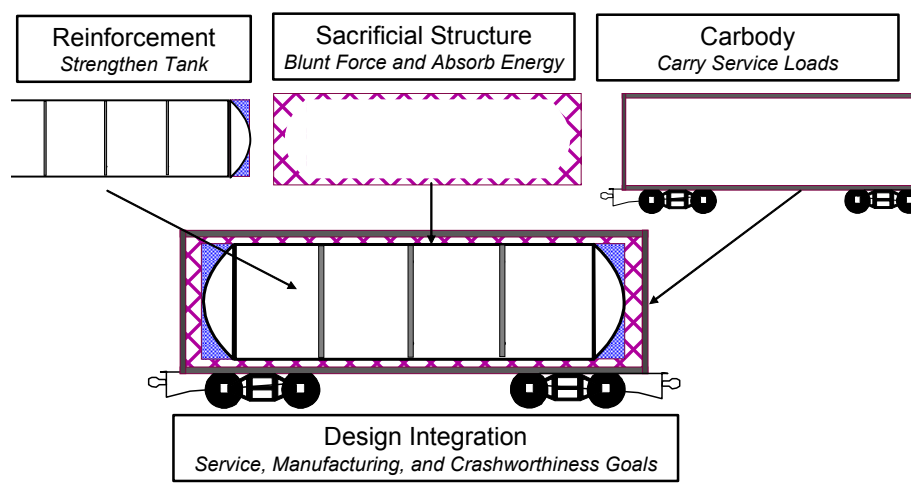

Figure 15. Preliminary Design Studies

The crashworthiness components shown in Figure 15 are being individually evaluated and integrated together to achieve an improved tank car design. The improved conceptual tank car design is being further developed in support of FRA regulatory efforts to show that a tank car can retain its lading for head and shell impact with four times the energy as the impact for which the baseline tank car can retain its lading. Meeting this goal doubles the impact speed for which the integrity of the tank can be maintained. As described in references $[8,9]$, the impact energy and speed depend upon the height and width of the nose of the blunt punch. The relative increase in performance sought is the same for a wide range of nose sizes.

Comparison of the conceptual design performance with the baseline performance results in the potential benefits of the improved conceptual design. The design development demonstrates the analysis and test techniques needed for assuring a level of performance in the generalized scenarios. The conceptual design illustrates the technologies that can contain the lading in the generalized scenarios at prescribed impact speeds.

\section{SUMMARY AND NEXT STEPS}

A framework has been developed for screening alternative strategies for increased tank car safety in train accidents. This framework acts as a roadmap for developing and evaluating potentially improved designs. As part of this framework, generalized head and shell impact scenarios have been developed. The baseline performance in the shell impact scenario has been evaluated with analyses and tests. The functions and features of an improved design have been identified. 
Current Volpe Center efforts are focused on developing a conceptual improved tank car design. Preliminary studies of available weight and space, strategies for blunting impact loads, means of energy absorption, and arrangements for strengthening the head and shell, as well as development of a carbody structure conceptual design, are also ongoing. A companion paper presents results to date of these preliminary design studies [10]. Component tests are tentatively planned to confirm (or refute) the results of selected substructure analyses being conducted as part of the conceptual design development.

Recent accidents involving the release of hazmat, with consequent fatalities, have focused attention on the structural integrity of railroad tank cars. The research described in this paper is being conducted to develop strategies for improving railroad tank cars so they can maintain tank integrity in severe accidents. The NGRTC Project is using these research results to help develop improved tank car designs. FRA and PHMSA intend to use these research results to support rulemaking.

\section{ACKNOWLEDGMENTS}

FRA, Office of Research and Development, sponsored the work described in this paper. Ms. Claire Orth is the Chief of the Equipment and Operating Practices Division. Mr. Francisco Gonzalez is the FRA project manager for research on railroad tank cars.

Mr. Grady Cothen, Deputy Associate Administrator for Safety Standards and Program Development, FRA, is leading the effort to develop tank car safety standards. The authors thank Ms. Jo Strang, Associate Administrator for Safety Enforcement, FRA, for her efforts to coordinate the standards development and tank car safety research.

Ms. Michelle Priante, Mechanical Engineer, Volpe Center, coordinated the design of the full-scale tests, analyzed the collision dynamics of the tests, and is assisting in development of the improved conceptual design. Mr. Jeff Gordon, Senior Engineer; Ms. Yim H. Tang, Senior Engineer, Volpe Center; and Dr. Hailing Yu, Chenga Advance Solutions \& Engineering, LLC; assisted in the design of the full-scale tests and performed the simplified finite-element analysis of the tests. Mr. Brandon Talamini, Senior Engineer; Mr. Michael Carolan, Mechanical Engineer; and Mr. Philip Mallon, Mechanical Engineer, Volpe Center; are coordinating the development of the improved conceptual tank car design. Finally, the authors would like to thank Professor A. Benjamin Perlman, Senior Engineer, Volpe Center, for his assistance through all aspects of this project.

\section{REFERENCES}

[1] National Transportation Safety Board, 2004: "Derailment of Canadian Pacific Railway Freight Train 292-16 and Subsequent Release of Anhydrous Ammonia Near Minot, North Dakota; January 18, 2002," Railroad Accident Report NTSB/RAR-04/01.

[2] National Transportation Safety Board, 2006: "Collision of Union Pacific Railroad Train MHOTU-23 with BNSF Railway Company Train MEAP-TUL-126-D with
Subsequent Derailment and Hazardous Materials Release, Macdona, Texas, June 28, 2004," Railroad Accident Report NTSB/RAR-06/03.

[3] National Transportation Safety Board, 2005: "Collision of Norfolk Southern Freight Train 192 with Standing Norfolk Southern Local Train P22 with Subsequent Hazardous Materials Release at Graniteville, South Carolina, January 6, 2005," Railroad Accident Report NTSB/RAR-05/04.

[4] Hutchinson, H. "Containing Risk," Mechanical Engineering, Vol. 129/No. 6, June 2007, American Society of Mechanical Engineers, New York, NY.

[5] Pipeline and Hazardous Materials Safety Administration, "Hazardous Materials: Improving the Safety of Railroad Tank Car Transportation of Hazardous Materials," Notice of Public Meeting, Federal Register, Vol. 71, No. 222, Friday, November 17, 2006.

[6] Federal Railroad Administration, "Development of New Federal Design Standards for Hazardous Materials Tank Cars to Benefit from Public-Private Partnership," U.S. Department of Transportation, FRA02-07, Tuesday, January 16, 2007.

[7] Jeong, D.Y., Lyons, M.L., Orringer, O., Perlman, A.B., 2007: "Equations of Motion for Train Derailment Dynamics," Proceedings of 2007 ASME Rail Transportation Division Fall Technical Conference, RTDF2007-46009.

[8] Yu, H., Jeong, D.Y., Gordon, J.E., Tang, Y.H., “Analysis of Impact Energy to Fracture Un-notched Charpy Specimens Made from Railroad Tank Car Steel," Proceedings of 2007 ASME Rail Transportation Division Fall Technical Conference, RTDF2007-460xx.

[9] Tang, Y.H., Yu, H., Gordon, J.E., Priante, M., Jeong, D.Y., Tyrell, D.C., Perlman, A.B., 2007: “Analysis of Full-Scale Tank Car Shell Impact Tests," Proceedings of 2007 ASME Rail Transportation Division Fall Technical Conference, RTDF2007-46010.

[10] Tyrell, D.C., Jacobsen, K., Talamini, B., Carolan, M., 2007, "Developing Strategies for Maintaining Tank Car Integrity During Train Accidents," Proceedings of 2007 ASME Rail Transportation Division Fall Technical Conference, RTDF2007-46015.

[11] Paetsch, C.R., Perlman, A.B., Jeong, D.Y., 2006: "Dynamic Simulation of Train Derailments," Proceedings of IMECE2006, 2006 ASME International Mechanical Engineering Congress and Exposition, IMECE200614607.

[12] Tyrell, D., Jacobsen, K., Martinez, E., “A Train-to-Train Impact Test of Crash Energy Management Passenger Rail Equipment: Structural Results," American Society of Mechanical Engineers, Paper No. IMECE2006-13597, November 2006.

[13] Martinez, E., Tyrell, D., Rancatore, R., Stringfellow, R., Amar, G., "A Crush Zone Design for an Existing Passenger Rail Cab Car," American Society of Mechanical Engineers, Paper No. IMECE2005-82769, November 2005. 
[14] Martinez, E., Tyrell, D., Perlman, A.B. , "Development of Crash Energy Management Designs for Existing Passenger Rail Vehicles," American Society of Mechanical Engineers, Paper No. IMECE2004-61601, November 2004.

[15] Mayville, R., Stringfellow, R., Johnson, K., Tyrell, D., "Rail Vehicle Car Cab Collision and Corner Post Designs According to APTA S-034 Requirements," American Society of Mechanical Engineers, Paper No. MECE200344114, November 2003.

[16] Tyrell, D., Severson, K., Marquis, B., Martinez, E., Mayville, R., Rancatore, R., Stringfellow, R., Hammond, R., Perlman, A.B., "Locomotive Crashworthiness Design Modifications Study," Proceedings of the 1999 IEEE/ASME Joint Railroad Conference, Institute of Electrical and Electronics Engineers, Catalog Number 99CH36340, 1999.

[17] Parent, D., Tyrell, D., Rancatore, R., Perlman, A.B., "Design of a Workstation Table with Improved Crashworthiness Performance," American Society of Mechanical Engineers, Paper No. IMECE2005-82779, November 2005.

[18] Severson, K., Tyrell, D., Rancatore, R., "Crashworthiness Requirements for Commuter Rail Passenger Seats," American Society of Mechanical Engineers, Paper No. IMECE2005-82643, November 2005.

[19]Zolock, J., Tyrell, D., "Locomotive Cab Occupant Protection," American Society of Mechanical Engineers, Paper No. IMECE2003-44121, November 2003. 